\title{
EFFECT OF HARVEST TIME AND L-CYSTEINE AS AN ANTIOXIDANT ON FLESH BROWNING OF FRESH-CUT CHERIMOYA (Annona cherimola Mill.)
}

\author{
Reinaldo Campos-Vargas ${ }^{1, *}$, Bruno G. Defilippi ${ }^{1,}$, Paula Romero Q. ${ }^{2}$, Héctor Valdés G. ${ }^{3}$, \\ Paula Robledo M. ${ }^{4}$, and Humberto Prieto E. ${ }^{1}$
}

\begin{abstract}
A B S T R A C T
Browning development is the most important factor limiting the quality of fresh-cut cherimoya (Annona cherimola Mill.). However, there is little information available about its causes and methods of control. The effectiveness of L-cysteine $(0.125,0.25$ and $0.5 \%)$ in fresh-cut cherimoya harvested on two occasions (October and November) and stored for 6 and 12 days at $0{ }^{\circ} \mathrm{C}$ was studied. In order to understand the biological basis of browning, polyphenol oxidase (PPO) enzyme activity and total phenolic content in fresh-cut pieces were measured. Quality measurements and sensory analysis indicated that $0.5 \% \mathrm{~L}$-cysteine was somewhat effective in reducing browning development, without affecting other quality attributes. In terms of physiological parameters, PPO activity did not show differences between mature (at harvest) and ripe fruit (at processing) in both harvest times, but cherimoya fruits picked in November presented lower PPO activity than fruit from October. In general, PPO activity and total phenolic content of L-cysteine treated fruits did not show consistent differences with untreated fruit at 6 or 12 days at $0{ }^{\circ} \mathrm{C}$. PPO activity analyses demonstrated that PPO activity was higher in the outer part of cherimoya flesh compared to the middle or inner sector. These results would support the possibility of using L-cysteine as a postharvest treatment to reduce browning development in fresh-cut cherimoya.
\end{abstract}

Keywords: antioxidants, Annona cherimola, polyphenol oxidase, phenolics, sensorial evaluation.

\section{INTRODUCTION}

The cherimoya is an exotic sub-tropical fruit with relevant sensorial characteristics. Chile is one of the southern places where cherimoyas are grown commercially in South America. Among cherimoya cultivars present in Chile, 'Concha Lisa' is the most important and has been described as more tolerant to low temperatures (Lahoz et al., 1993). This variety has been considered appropriate for export markets. However, fresh cherimoya export is restrictive because of the fruit's high perishability and susceptibility to chilling, forcing producers to use expensive airfreight (Palma et al., 1993). This situation has caused a reduction in the number of cherimoya orchards, with the consequent replacement with more profitable fruit species.

Minimally processed fruits are emerging as a new consumer trend based on their convenience (Wills et al., 1998). Cherimoya fruit is suitable for fresh-cut processing, especially considering its high number of seeds, large size and inedible peel, resulting in a significant non-edible proportion when consumed as a whole fresh fruit. Therefore, the fresh cut modality could be a new and more convenient way to offer fresh cherimoya fruit to consumers. However, the information available on cherimoya fruit is insufficient to estimate the changes resulting from minimal processing. It is known that the behavior of a fresh cut product could be different from that of the same product without processing (Watada et al., 1996; Gorny, 1997). Therefore, the production of fresh-cut cherimoya implies the study of the effects of minimal processing (such as peeling, cutting, and chunking) and the changes in behavior of the cherimoya pieces as a result of wounding. Cherimoya fruit is

\footnotetext{
${ }^{1}$ Instituto de Investigaciones Agropecuarias, Centro Regional de Investigación La Platina, Casilla 439/3, Santiago, Chile. E-mail: rcampos@inia.cl *Corresponding author.

${ }^{2}$ Universidad de Las Américas, Escuela de Agronomía, Manuel Montt 948, Santiago, Chile.

${ }^{3}$ Universidad de La Serena, Facultad de Ciencias, Cisternas 1200, La Serena, Chile.

${ }^{4}$ Universidad de Chile, Facultad de Ciencias Agronómicas, Santa Rosa 11315, Santiago, Chile. Received: 21 June $2007 . \quad$ Accepted: 21 August 2007.
} 
prone to browning (Martinez et al., 1993), which is considered one the most important oxidative reactions leading to loss of sensorial and nutritional quality (Amiot et al., 1997).

Studies have reported cysteine as an inhibitor of enzymatic browning in fruits (Amiot et al., 1997). Experiments with processed fruit including L-cysteine have shown promising results in reducing the browning problem (Gorny et al., 2002; Melo and Vilas-Boas, 2006). Therefore, the objective of this work was to evaluate the fruit harvest time and L-cysteine as a strategy for browning reduction of minimally processed cherimoya.

\section{MATERIALS AND METHODS}

\section{Plant material and processing}

Fruit was harvested from 'Concha Lisa' cherimoya trees grown in a commercial orchard located in Quillota Valley, Chile (32 $52^{\prime}$ S, $71^{\circ} 15^{\prime} \mathrm{W}$ ) in October and November, 2005. The change in fruit background color from dark to light green was considered as a harvesting index following technical orchard protocols. In general, large to medium size fruits were selected and transported to the postharvest laboratory facilities at the Agricultural Research Institute (INIA), Santiago, for ripening and preparation.

Preliminary studies showed that fruit must be processed when cherimoya is fully ripe, with firmness values close to 1 kilogram force (kgf), since pieces from mature (unripe) firm cherimoya did not follow a normal ripening process during cold storage (data not shown). Before processing, fruit was washed with a $100 \mathrm{mg} \mathrm{L}^{-1}$ $\mathrm{NaOCl}$ water solution at room temperature to eliminate surface contamination. Then, fruit was hand-peeled with a sharp knife, deseeded and the pieces were immersed 2 min in a solution containing an antioxidant compound, L-cysteine, and then drained for $1 \mathrm{~min}$. The L-cysteine solutions studied were $0.125,0.25$ and $0.5 \% \mathrm{w} / \mathrm{w}$. Fruit pieces from control treatment were immersed in water and drained for similar time. Fresh-cut cherimoyas were stored in $0.5 \mathrm{~L}$ plastic containers at $0{ }^{\circ} \mathrm{C}$ for 6 and $12 \mathrm{~d}$. For all experiments fruit was kept at $90-95 \%$ relative humidity.

\section{Maturity and quality parameters}

At harvest, during the ripening process and after storage in cold room conditions, fruit maturity and quality parameters were measured. The firmness of the whole fruit was evaluated by using a penetrometer
(Fruit Pressure Tester, FT327, Alfonsine, Italy) with an $8 \mathrm{~mm}$ plunger on two opposite sides of the fruit previously peeled. Total soluble solids (TSS) were measured by a temperature-compensated refractometer (ATAGO, ATC-1, Tokyo, Japan) and expressed as the percentage of soluble solids in juice. Titratable acidity (TA), expressed as malic acid, was determined by adding $0.2 \mathrm{~N} \mathrm{NaOH}$ to $10 \mathrm{~mL}$ cherimoya juice until pH 8.2 (Alique, 1995). Starch pattern was measured by spraying the cherimoya flesh with an iodine solution ( $24 \mathrm{~g} \mathrm{KI}$ and $12 \mathrm{~g} \mathrm{I}_{2}$ per liter double distilled water) and ranking the color development in a scale from 1 (high starch content) to 10 (very low starch content), in a similar way to that used in apple starch index scoring (de Castro et al., 2007). The same methodology was used for fresh cut pieces, with the exception of firmness and starch content analyses.

The relative concentration of soluble $o$-quinones was measured as described by Loaiza-Velarde and Saltveit (2001). Briefly, $10 \mathrm{~g}$ of cherimoya pulp was ground with methanol (1:2), filtered and centrifuged at $15000 \mathrm{xg}$ for $15 \mathrm{~min}$. The supernatant was measured to $437 \mathrm{~nm}$ in a spectrophotometer (Shimadzu UV-1700, Kyoto, Japan).

The fresh pulp color measurement was done using a chromameter (Minolta CR-300, Osaka, Japan), recording the data in lightness $\left(\mathrm{L}^{*}\right)$, chromaticity $\left(\mathrm{a}^{*}\right.$ and $\left.b^{*}\right)$, Chroma $\left(\left[\left(a^{*}\right)^{2}+\left(b^{*}\right)^{2}\right]^{0.5}\right)$ and Hue angle $\left(\tan ^{-1}\left[\left(\mathrm{~b}^{*}\right)\left(\mathrm{a}^{*}\right)^{-1}\right]\right)$.

\section{Physiological parameters}

Immediately after harvest and before processing, ethylene production and respiration rates were determined in individual fruit using a static system. Five fruits were weighed and placed in $0.5 \mathrm{~L}$ jars at $20^{\circ} \mathrm{C}$. The jars were sealed for $3 \mathrm{~h}$ to obtain gas samples. Carbon dioxide concentrations were measured by injecting a $1 \mathrm{~mL}$ headspace sample in a gas analyzer (PIB Dansensor Checkmate 9900, Ringsted, Denmark). Ethylene was measured using a gas chromatograph (Shimadzu GC8A, Kyoto, Japan) equipped with a flame ionization detector (FID) and an alumina column.

\section{Polyphenol oxidase (PPO) activity evaluation}

PPO activity evaluation was done as described by Siriphanich and Kader (1985), with modifications. Briefly, cherimoya fruit samples were obtained and frozen until preparation. Four grams of cherimoya were ground in $12 \mathrm{~mL}$ buffer [0.1 M citric acid $(\mathrm{pH}$ 6.6), $5 \mathrm{mM}$ 2-Me, $0.4 \mathrm{~g}$ polyvinylpolypirrolidone]. 
The mixture was centrifuged at $20000 \mathrm{xg}$ for $10 \mathrm{~min}$ at $4{ }^{\circ} \mathrm{C} .0 .1 \mathrm{~mL}$ of supernatant was saved and added to $2.9 \mathrm{~mL}$ buffer [0.5 mM citric acid buffer ( $\mathrm{pH}$ 6.6) and $20 \mathrm{mM}$ cathecol]. The activity was measured in a Shimadzu UV-1700 spectrophotometer as product at $420 \mathrm{~nm}$ by $10 \mathrm{~min}$ at $25{ }^{\circ} \mathrm{C}$. The straight part of the curve was considered for activity calculations. A blank test containing only buffer or substrate did not show changes in absorbance in the assayed period. In addition, the use of sodium dodecyl sulfate (SDS) at $0.6 \mathrm{mM}$ (Rathjen and Robinson, 1992) was checked without observing any effect in PPO activity levels (data not shown). Therefore, SDS was not used in PPO activity analyses. The unit for PPO enzyme activity (U) was defined as the change of 0.001 absorbance value under the described conditions. Protein content of enzyme extracts was determined by the method of Bradford (1976), by using a Bio-Rad protein assay kit (Bio-Rad, Hercules, California, USA) and bovine serum albumin (BSA) as a standard. PPO activity was expressed as $\mathrm{U} \mathrm{min}{ }^{-1} \mathrm{mg}^{-1}$ total protein.

\section{Sensory evaluations}

Sensorial evaluations were performed by a panel composed of 12 judges. Briefly, $40 \mathrm{~g}$ of fruit pieces from different treatments were taken and placed in trays for evaluations in closed rooms. The methodology of descriptive tests was followed (Piagentini et al., 2005), using a scale from 0 to 15 . For appearance and aroma, 0 corresponded to unsatisfactory and 15 to satisfactory. In the case of browning development, 0 meant a sound tissue and 15 a completely brown tissue.

\section{Total phenolics}

Total phenolic compounds were quantified by the Folin-Ciocalteu spectrophotometric method (Singleton and Rossi, 1965). Data were reported as milligrams of $p$-coumaric acid $\mathrm{g}^{-1}$ fresh weight (FW).

\section{Statistical analysis}

There were three replicates (one pot of $800 \mathrm{~g}$ each) for all the evaluations. Data were subjected to analysis of variance, and means were separated by least significant difference (LSD) test at 5\% significance level using Statgraphics Plus 5 (Manugistics Inc., 2000).

\section{RESULTS AND DISCUSSION}

\section{Maturity and physiological parameters}

Since the quality of the fresh cut product relies on the characteristics of raw material, cherimoya fruits at two harvest times (October and November) were analyzed, which permitted studying potential changes in physiological behavior or fruit disorder susceptibility associated with environmental changes (GonzalezAguilar et al., 2000; Campos-Vargas et al., 2006). A remarkable loss of fruit firmness between harvest and processing, with a reduction close to $17-15 \mathrm{kgf}$, was observed at both harvest times (Table 1).

Total soluble solids content (TSS) in ripe fruit processed in October or November increased substantially, doubling the amount measured in fruits just after harvest. These changes are similar to those reported in other cherimoya studies (Lahoz et al., 1993; Alique et al., 1994; Sanchez et al., 1998). The significant increase in TSS could be due to the breakdown of starch at ripening (Martinez et al., 1993), as is supported by the high starch index value of ripe cherimoya fruit at both harvest times. Titratable acidity (TA) levels, although low through ripening, increased in ripe fruits in both harvest times. The rise of TA at ripening has

Table 1. Maturity parameters at harvest (mature) and before processing (ripe) of cherimoya fruit harvested in October (Harvest 1) and November (Harvest 2).

\begin{tabular}{|c|c|c|c|c|}
\hline $\begin{array}{c}\text { Time of } \\
\text { evaluation }\end{array}$ & Firmness & $\begin{array}{c}\begin{array}{c}\text { Total soluble } \\
\text { solids }\end{array} \\
\end{array}$ & Titratable acidity & $\begin{array}{c}\text { Starch index }{ }^{1} \\
(1-10)\end{array}$ \\
\hline & $\mathrm{kgf}$ & $\%$ & $\%$ malic acid & \\
\hline & \multicolumn{4}{|c|}{ Harvest 1} \\
\hline At harvest & $18.20 \mathrm{~b}$ & $6.2 \mathrm{a}$ & $0.1 \mathrm{a}$ & $1.0 \mathrm{a}$ \\
\hline At processing & $1.06 \mathrm{a}$ & $15.4 \mathrm{~b}$ & $0.3 \mathrm{c}$ & $9.4 \mathrm{c}$ \\
\hline & \multicolumn{4}{|c|}{ Harvest 2} \\
\hline At harvest & $16.50 \mathrm{~b}$ & $7.5 \mathrm{a}$ & $0.1 \mathrm{a}$ & $1.0 \mathrm{a}$ \\
\hline At processing & $0.83 \mathrm{a}$ & $15.5 \mathrm{~b}$ & $0.2 b$ & $8.4 \mathrm{~b}$ \\
\hline
\end{tabular}


been explained by the synthesis of malic acid due to the action of malate dehydrogenase activity as cherimoya fruit ripens (Muñoz et al., 2004). In terms of physiological parameters, there was a progression of both, ethylene and respiration rates between mature and ripe cherimoya (Table 2), following the expected pattern for climacteric fruit (Kader, 2002a). It is interesting to observe the major increase of ethylene production in 'Concha Lisa' cherimoya from undetectable levels at harvest to remarkable amounts at processing. This high rate of ethylene production is also shared with other cherimoya cultivars, such as Fino de Jete (Martinez et al., 1993; Sanchez et al., 1998), allowing thus the classification of cherimoya fruit as a very high ethylene producer (Kader, 2002a).

After processing, the quality parameters in fruit pieces were studied. TSS and TA content after 6 and $12 \mathrm{~d}$ storage at $0{ }^{\circ} \mathrm{C}$ from both harvest times, and with different concentrations of L-cysteine, did not show significant changes (data not shown). This situation can be explained since the fruits were processed when the changes associated with ripening were already accomplished, obtaining the maximum soluble solids and acidity levels, which were maintained without changes in storage due to the low temperature used in the experiment. It is interesting that cherimoya, being a chilling sensitive fruit (Palma et al., 1993; Alique et al., 1994; Gutierrez et al., 1994), did not show a reduction of soluble solids or acidity, as seen in other situations of chilling response (Marrero and Kader, 2006). Similarly, Gil et al. (2002), working in modified atmosphere packaging of fresh cut tomato (Lycopersicon esculentum Mill.), concluded that the best temperature for keeping quality was $0{ }^{\circ} \mathrm{C}$, a chilling condition for raw tomato. Cantwell and Suslow (2002) stated that the postharvest life of fresh cut products prepared from chilled sensitive commodities is longer at $0{ }^{\circ} \mathrm{C}$ than at warmer temperatures, since the deterioration induced by low temperatures is less detrimental than decay at higher temperature.

\section{Browning development}

The $\mathrm{L}^{*}$ (lightness) of treatments with L-cysteine was not different from control after 6 and $12 \mathrm{~d}$ storage in harvest 1 (October) and after $6 \mathrm{~d}$ storage in harvest 2 (November) (Table 3). For harvest 2, only after 12 $\mathrm{d}$ storage the $\mathrm{L}^{*}$ value from 0.25 or $0.5 \% \mathrm{~L}$-cysteine treated fruits was different from control. As well, all treatments at harvest 1 and $0.5 \%$ of L-cysteine in harvest 2 were similar to $L^{*}$ at processing. This lack of shift in terms of $\mathrm{L}^{*}$ in stored fresh cut cherimoya could be induced by a reduction of lightness caused by changes in the physical or optical properties of the flesh. Other researchers have reported that $\mathrm{L}^{*}$ was not modified by antioxidant treatment in different fresh cut pear (Pyrus communis L.) cultivars, concluding that chromaticity a* value was the most effective to evaluate color changes (Buta and Abbott, 2000). The $\mathrm{a}^{*}$ values of $0.5 \%$ L-cysteine of harvest 1 , after 6 or $12 \mathrm{~d}$ storage, and harvest 2 after $6 \mathrm{~d}$ storage, were statistically similar to those observed at processing. Although $\mathrm{a}^{*}$ with $0.5 \%$ L-cysteine treatment after $12 \mathrm{~d}$ storage in harvest 2 was different from cherimoya at processing, it was ranked over the rest of the treatments. The results of a* could be linked to the reduction of browning development in cherimoya by L-cysteine. Other authors have described that $\mathrm{a}^{*}$ showed the best correlation with browning in fresh cut apple (Malus domestica Borkh.) and lettuce (Lactuca sativa L.) (Rocha and Morais, 2001).

Table 2. Physiological parameters at harvest (mature) and before processing (ripe) of cherimoya fruits harvested in October (Harvest 1) and November (Harvest 2).

\begin{tabular}{lcc}
\hline \multicolumn{1}{c}{ Time of evaluation } & $\begin{array}{c}\text { Ethylene } \\
\text { production rate }\end{array}$ & Respiration rate \\
\hline & $\mu \mathrm{L} \mathrm{kg}^{-1} \mathrm{~h}^{-1}$ & $\mathrm{~mL} \mathrm{CO}_{2} \mathrm{~kg}^{-1} \mathrm{~h}^{-1}$ \\
& \multicolumn{2}{c}{ Harvest 1} \\
& $0.0 \mathrm{a}$ & $17.8 \mathrm{a}$ \\
At harvest & $56.4 \mathrm{~b}$ & $53.7 \mathrm{~b}$ \\
At processing & $0.0 \mathrm{a}$ & Harvest 2 \\
& $76.8 \mathrm{~b}$ & $12.1 \mathrm{a}$ \\
At harvest & $53.9 \mathrm{~b}$ \\
At processing & &
\end{tabular}




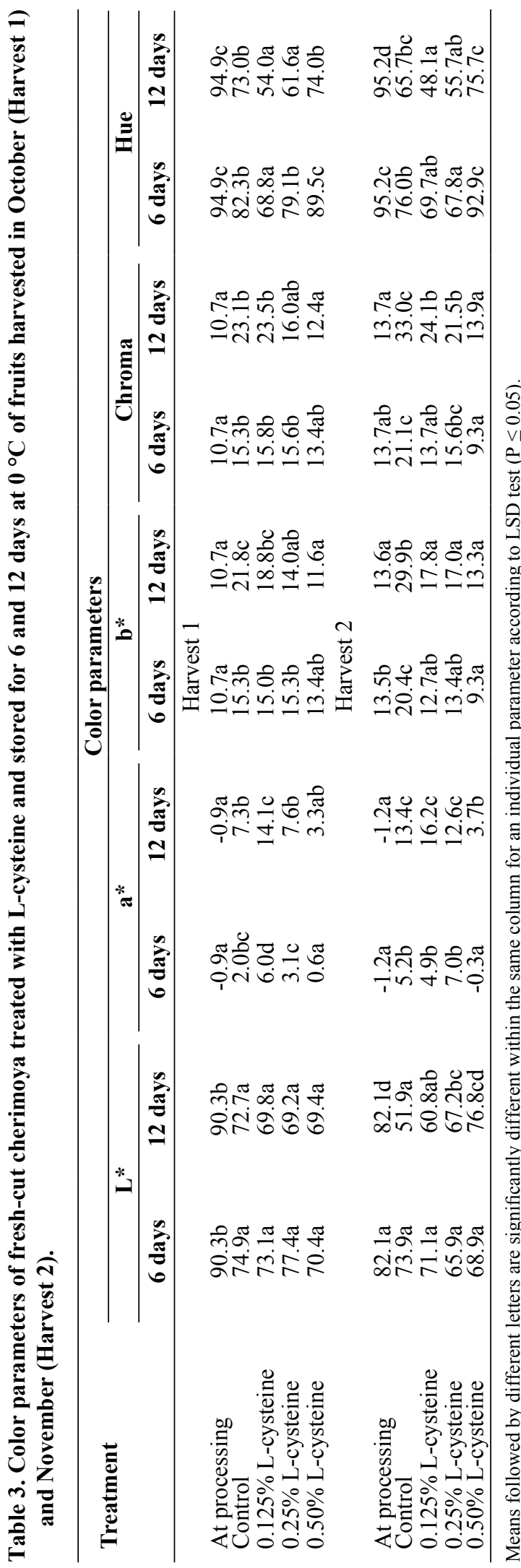

The chromaticity $b^{*}$ value from $0.5 \%$ L-cysteine treatments showed a trend to present lower values than the rest of the treatments and similar to those observed at processing. In relation to Chroma, excluding the evaluation after $6 \mathrm{~d}$ in harvest 1 , values of treatments with $0.5 \%$ L-cysteine were similar to cherimoya at processing. Hue angles of cherimoyas at processing were similar to those treated with $0.5 \%$ of cysteine and stored for $6 \mathrm{~d}$ at $0{ }^{\circ} \mathrm{C}$ for both harvest times. However, hue angles of cherimoya stored for $12 \mathrm{~d}$ with L-cysteine were lower than at processing, with no evident pattern, probably due to the intense browning registered in all treatments (Figure 1). The inconsistent effect of 0.125 and $0.25 \%$ L-cysteine could be explained by an insufficient amount of L-cysteine achieving a cysteine:phenolic ratio appropriate for inducing synthesis of colored products by $o$-quinone reactions (Amiot et al., 1997).

The sensory evaluation of aroma, appearance and browning of fresh cut cherimoya is shown in Figure 1. Aroma was not affected by treatments or low temperature as judged by the panel in both harvest times, which is highly desirable since L-cysteine treatments did not add off-odors to cherimoya. The highest score of appearance was obtained from cherimoya fruits treated with increasing concentrations of L-cysteine in both harvest times. The treatment with $0.5 \% \mathrm{~L}-$ cysteine was more effective than others in reducing browning in short- or long-term storage. However, after $12 \mathrm{~d}$, the overall visual quality was lower than after $6 \mathrm{~d}$ at $0{ }^{\circ} \mathrm{C}$. A higher intensity of browning was observed in pieces obtained from the outer zone of the fruit (below the rind) than from other zones in the flesh. As stated by judges, treatments with 0.125 and $0.25 \%$ L-cysteine also reduced browning development, although the highest concentration was more consistent in accordance with the instrumental analyses data in Table 3. Interestingly, L-cysteine treatments did not affect taste of cherimoya pieces, as stated by judges (data not shown). The action of L-cysteine as an inhibitor of browning development has been referred to in its capacity for abduction of phenolic compounds, reduction of $o$-quinones to diphenols, competitive inhibition of PPO and phenol regeneration (RichardForget et al., 1992). These data suggest that L-cysteine at $0.5 \%$ could be a promising antioxidant treatment in cherimoya. However, our data contrast with those obtained by Martinez-Cayuela et al. (1988), who concluded that thiol compounds, such as L-cysteine, could not inhibit browning in cherimoya. The lack of correlation between instrumental and sensorial results could be induced by the nature of the cherimoya 


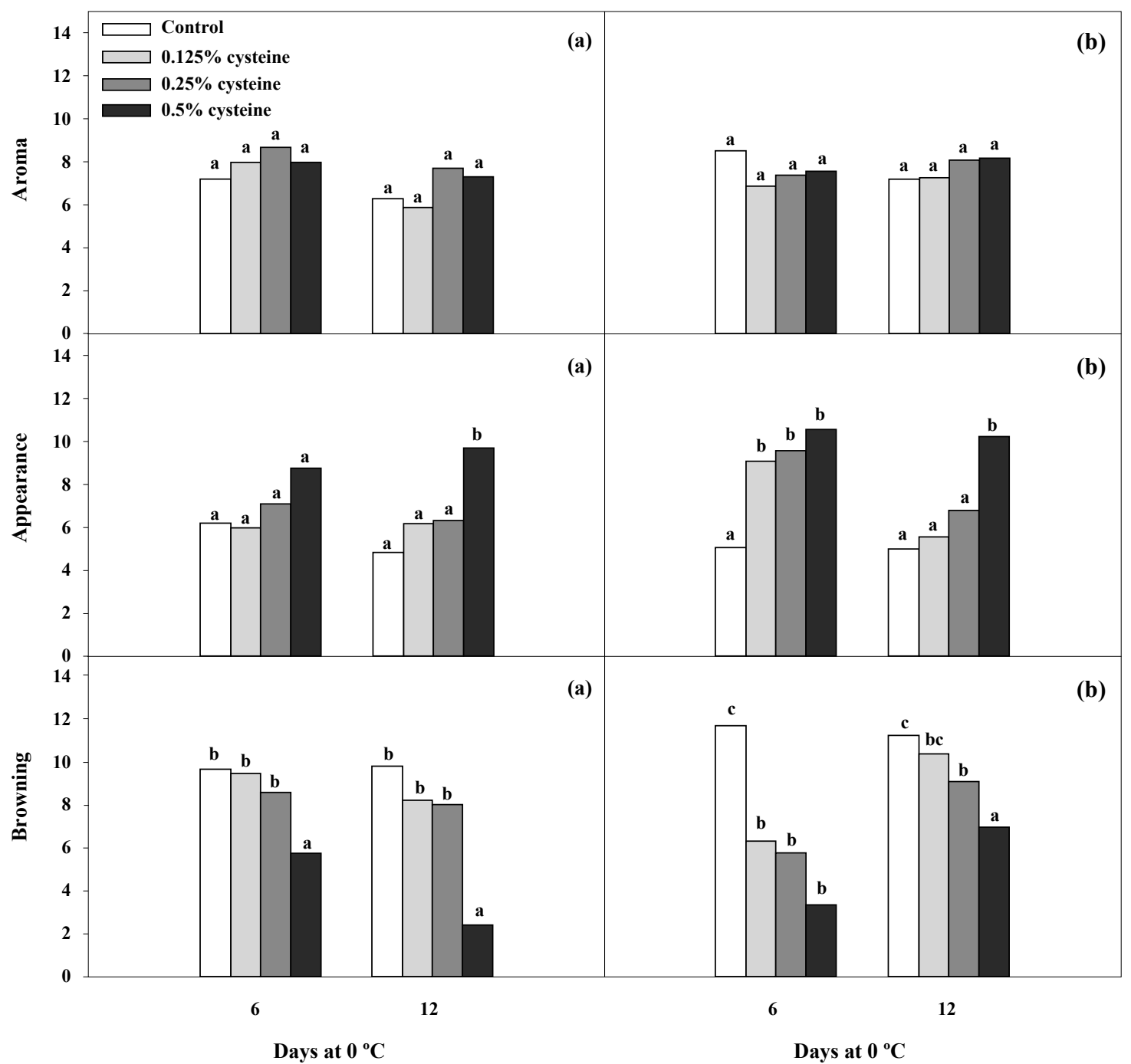

Figure 1. Sensory evaluations from fresh-cut cherimoya treated with L-cysteine and stored for 6 and $12 \mathrm{~d}$ at $0{ }^{\circ} \mathrm{C}$. Harvest October (a) and November (b). For appearance and aroma 0 corresponds to unsatisfactory and 15 to satisfactory. In the case of browning development 0 means a sound tissue and 15 a completely brown tissue. Means followed by different letters are significantly different according to LSD test $(\mathrm{P} \leq 0.05)$.

flesh, as stated before, and the fact that cherimoya is an aggregate fruit (derived from a single flower with several pistils). Therefore, the judges could have a more integral view of the general aspect of the pieces and the instrumental data analyses could be interfered with by the type of tissue sampled in terms of topological localization in the cherimoya flesh (close to the core or the outside part of the fruit).

\section{Total phenolics and PPO activity}

The total phenolic content from fruit harvested in October did not show significant changes between mature (at harvest) and ripe fruit (at processing) (Table 4). The absence of differences between maturity stages has been reported by Assis et al. (2001). However, phenolic content of mature cherimoyas harvested in November showed lower values than ripe fruits. In addition, cherimoyas from the second harvest had lower levels of total phenolics at the mature stage than fruit picked in October, but after ripening both harvests were similar. These differences could be due to the different environmental conditions in which they were grown, which could be affecting the phenolic content (Kader, 2002b). 
Despite the absence of statistical differences in PPO activity between mature (at harvest) and ripe fruit (at processing) for both harvest times (Table 4), the enzyme activity levels of mature or ripe fruits harvested in October were significantly higher than of those picked later in November, which could be explained as result of more favorable environmental conditions later in the season, which influence cherimoya metabolism analogous to the explanation for phenolic content. The lack of statistical difference in PPO activity related to ripening progress has been observed in other fruits (Valentines et al., 2005). A relation between PPO activity and total phenolic content in cherimoya harvested on October or November was not evident (Table 4). The latter could indicate that the synthesis of phenolic compound does not present a direct relationship to PPO activity, as reported with other fruits. Rocha and Morais (2001) reported a $\mathrm{R}^{2}=0.29$ between phenolic content and
PPO activity in minimally processed apples. According to Cheng and Crisosto (1995), PPO activity did not correlate with browning potential in peach (Prunus persica (L.) Batsch) and nectarine skins.

The phenolic content and PPO activity of fresh-cut cherimoya after 6 and $12 \mathrm{~d}$ storage at $0{ }^{\circ} \mathrm{C}$ is shown in Table 5. The total phenolic content in both harvests did not show a consistent trend. In harvest 1 , after $6 \mathrm{~d}$, total phenolics of untreated fruit did not differ from that of fruit treated with different percentages of L-cysteine, but after $12 \mathrm{~d}$ non-treated fruit had less phenolic compounds than $0.5 \%$ L-cysteine-treated fruit. The latter contrasts with harvest 2 data, where after $6 \mathrm{~d}$ the control showed less total phenolics than the treatment with $0.5 \%$ L-cysteine, but after $12 \mathrm{~d}$ all treatments were statistically similar. However, total phenolics for all treatments after $6 \mathrm{~d}$ were higher than

Table 4. Total phenolics and polyphenol oxidase (PPO) activity at harvest (mature) and before processing (ripe) of cherimoya fruits picked in October and November.

\begin{tabular}{|c|c|c|c|c|}
\hline \multirow[t]{2}{*}{ Evaluation } & \multicolumn{2}{|c|}{ Total phenolics } & \multicolumn{2}{|c|}{ PPO activity } \\
\hline & October & November & October & November \\
\hline & \multicolumn{2}{|c|}{$\mu \mathrm{gg}(\mathrm{FW})^{-1}$} & \multicolumn{2}{|c|}{$\mathrm{U} \mathrm{min}^{-1} \mathrm{mg}^{-1}$ total protein } \\
\hline At harvest & $103.4 \mathrm{aA}$ & $63.1 \mathrm{aB}$ & $4282 \mathrm{aA}$ & $1007 \mathrm{aB}$ \\
\hline At processing & $117.8 \mathrm{aA}$ & $97.7 \mathrm{bA}$ & 2988aA & $675 \mathrm{aB}$ \\
\hline
\end{tabular}

Means followed by different lower-case letters are significantly different within the same column and capital letter within the same row for an individual parameter according to LSD test $(\mathrm{P} \leq 0.05)$.

FW: fresh weight.

Table 5. Total phenolics and polyphenol oxidase (PPO) activity of fresh-cut cherimoya fruits treated with L-cysteine and stored for 6 and 12 days at $0{ }^{\circ} \mathrm{C}$ of fruits harvested in October (Harvest 1) and November (Harvest 2).

\begin{tabular}{|c|c|c|c|c|}
\hline \multirow[t]{2}{*}{ Treatment } & \multicolumn{2}{|c|}{ Total phenolics } & \multicolumn{2}{|c|}{ PPO activity } \\
\hline & 6 days & 12 days & 6 days & 12 days \\
\hline & \multicolumn{2}{|c|}{$\mu \mathrm{g} \mathrm{g}^{-1} \mathrm{FW}$} & \multicolumn{2}{|c|}{$\mathrm{U} \mathrm{min}^{-1} \mathrm{mg}^{-1}$ total protein } \\
\hline & \multicolumn{4}{|c|}{ Harvest 1} \\
\hline Control & $127.9 \mathrm{ab}$ & $92.3 \mathrm{a}$ & $2926 a$ & $1944 \mathrm{a}$ \\
\hline $0.125 \%$ L-cysteine & $105.0 \mathrm{a}$ & $88.7 \mathrm{a}$ & $2448 \mathrm{a}$ & $1517 \mathrm{a}$ \\
\hline $0.25 \%$ L-cysteine & $128.0 \mathrm{ab}$ & $112.5 \mathrm{ab}$ & $1867 \mathrm{a}$ & $1631 \mathrm{a}$ \\
\hline \multirow[t]{2}{*}{$0.5 \%$ L-cysteine } & $153.7 \mathrm{~b}$ & $135.6 \mathrm{~b}$ & $1680 \mathrm{a}$ & $1005 \mathrm{a}$ \\
\hline & \multicolumn{4}{|c|}{ Harvest 2} \\
\hline Control & $135.8 \mathrm{a}$ & $81.7 \mathrm{a}$ & $1724 b$ & $1232 \mathrm{a}$ \\
\hline $0.125 \%$ L-cysteine & $134.0 \mathrm{a}$ & $92.3 \mathrm{a}$ & $1056 \mathrm{ab}$ & $1156 \mathrm{a}$ \\
\hline $0.25 \%$ L-cysteine & $143.7 \mathrm{a}$ & $83.4 \mathrm{a}$ & $1221 \mathrm{ab}$ & $765 \mathrm{a}$ \\
\hline $0.5 \%$ L-cysteine & $173.8 \mathrm{~b}$ & $95.8 \mathrm{a}$ & $470 \mathrm{a}$ & $979 \mathrm{a}$ \\
\hline
\end{tabular}

Means followed by different letters are significantly different within the same column and harvest time for an individual parameter according to LSD test $(\mathrm{P} \leq 0.05)$.

FW: fresh weight. 
after $12 \mathrm{~d}$ in both harvests, probably as result of the reduction of the pool of phenolics by polymerization ending in brown compounds or other reactions. This pattern of increase of total phenolic contents followed by reduction has been described in cubes of apple stored at $4{ }^{\circ} \mathrm{C}$ (Rocha and Morais, 2001).

In general, PPO activity levels of minimally processed cherimoya (Table 5) treated and non-treated with antioxidant solution were not statistically different. Couture et al. (1993) working with fresh cut lettuce reported no changes in PPO activity after $4 \mathrm{~d}$ at 2.5 ${ }^{\circ} \mathrm{C}$. Similarly, Ke and Saltveit (1989) did not observe changes in PPO activity after wounding of iceberg lettuce (Lactuca sativa L.). The reason why only cherimoya treated with $0.5 \%$ L-cysteine had significantly lower PPO activity than control after $6 \mathrm{~d}$ in harvest 1 is unclear. An explanation could be that cherimoya actually corresponds to a syncarpium fruit (Palma et al., 1993); therefore, data represents PPO activity of several fruitlets providing an extra level of complexity in the analysis as observed previously for other metabolic processes (Biale and Barcus, 1970).

As mentioned above, browning development was higher in pieces obtained close to the peel than in the inner part of the fruit. In order to understand this situation, total phenolic content and PPO activity were measured in tissue derived from different positions in the flesh (Table 6). Phenolic contents were statistically higher in tissue from outer than inner or middle parts of the fruit. The same pattern was shown after $4 \mathrm{~h}$ at $20^{\circ} \mathrm{C}$, but pieces from outer and middle parts of the fruit showed an increase of total phenolics with almost null changes in the inner part. PPO activity of the same pieces showed higher values in the outer and middle flesh at time 0 , with a lower level in the inner zone. After exposing pieces to air at $20^{\circ} \mathrm{C}$ for $4 \mathrm{~h}, \mathrm{PPO}$ activity in the outer part doubled the levels observed at time 0 , explaining partially the rise in total phenolic content recorded in this zone of the fruit. The PPO activity of the middle or inner part did not show a major increment and remained low. These results would suggest differential susceptibility to browning of cherimoya fruit zones. Sanchez de Medina et al. (1986) reported a higher PPO activity in exocarp than mesocarp in cherimoya cv. Fino de Jete. Rivas and Whitaker (1973) purified PPO from pear peel because this tissue had significantly more activity than pulp. Gooding et al. (2001) described in full size green bananas (Musa $\mathrm{x}$ paradisiaca $\mathrm{L}$.) almost double PPO activity in the peel than the pulp. Rathjen and Robinson (1992) found higher PPO activity in skin compared with pulp in grape (Vitis vinifera $\mathrm{L}$.) berries 'Sultana H5'. Japanese apples showed the highest PPO activity in the core, followed by the flesh and then the peel (Wakayama, 1995).

\section{CONCLUSIONS}

This work reported the complexity of cherimoya fruits as a fresh cut product and the physiological changes induced by processing. In general, PPO activity of cherimoya harvested in November was lower than that measured in October. In addition, the inner part of the fruit showed less PPO activity and phenolic compounds than the tissue close to the peel, suggesting topological differences in cherimoya flesh. Besides, fresh cut cherimoya pieces were less brown at 6 than $12 \mathrm{~d}$ based on Hue angle data. Although the instrumental color analyses showed low correlation with the sensorial panel data, it is possible to conclude that low temperature and L-cysteine are suitable tools to keep the quality of fresh cut cherimoya by reducing the browning process. However, in future works it is required to find better techniques to instrumentally quantify color changes in cherimoya samples.

Table 6. Total phenolics and polyphenol oxidase (PPO) activity of cherimoya tissues after 4 $h$ at $20^{\circ} \mathrm{C}$.

\begin{tabular}{|c|c|c|c|c|}
\hline \multirow[t]{2}{*}{ Fruit tissue } & \multicolumn{2}{|c|}{ Total phenolics } & \multicolumn{2}{|c|}{ PPO activity } \\
\hline & $\mathbf{O H}$ & $4 \mathrm{~h}$ & $\mathbf{O} \mathbf{h}$ & $4 \mathrm{~h}$ \\
\hline & \multicolumn{2}{|c|}{$\mu \mathrm{g} \mathrm{g}^{-1} \mathrm{FW}$} & \multicolumn{2}{|c|}{$\mathrm{U} \mathrm{min}^{-1} \mathrm{mg}^{-1}$ total protein } \\
\hline Outer & $104.6 \mathrm{~b}$ & $123.2 b$ & $6961 \mathrm{a}$ & $12911 b$ \\
\hline Middle & $85.0 \mathrm{a}$ & $97.7 \mathrm{ab}$ & $5662 \mathrm{a}$ & $4950 \mathrm{a}$ \\
\hline Inner & $86.3 \mathrm{a}$ & $85.1 \mathrm{a}$ & $2183 b$ & $3581 \mathrm{a}$ \\
\hline
\end{tabular}

Means followed by different letters are significantly different within the same column and harvest time for an individual parameter according to LSD test $(\mathrm{P} \leq 0.05)$.

FW: fresh weight 


\section{R E S U M E N}

Efecto del momento de cosecha y L-cisteína como un antioxidante en el pardeamiento de pulpa de chirimoya (Annona cherimola Mill.) precortada. Reinaldo Campos-Vargas ${ }^{1, *}$, Bruno G. Defilippi ${ }^{1}$, Paula Romero Q. ${ }^{2}$, Héctor Valdés G. ${ }^{3}$, Paula Robledo M. ${ }^{4}$, y Humberto Prieto E. El desarrollo de pardeamiento es uno de los factores limitantes en la calidad de chirimoya (Annona cherimola Mill.) precortada (fresh-cut). No obstante, existe poca información disponible en relación a sus causas y métodos de control en esta fruta. Se estudió la efectividad de L-cisteína $(0,125 ; 0,25$ y $0,5 \%)$ en chirimoya precortada cosechada en dos oportunidades (octubre y noviembre) y almacenada por 6 y 12 días a $0^{\circ} \mathrm{C}$. Con el objetivo de conocer las bases biológicas del pardeamiento, se estudió la actividad de polifenol oxidasa (PPO) y contenido de fenólicos totales en piezas resultantes del precortado. Las mediciones de calidad y análisis sensorial indicaron que el tratamiento $0,5 \%$ L-cisteína fue el más efectivo en reducir el desarrollo de pardeamiento sin afectar otros atributos de calidad.
En términos de parámetros fisiológicos, la actividad de PPO no mostró diferencias entre frutos inmaduros (a la cosecha) y maduros (al procesamiento) en ambas cosechas. Sin embargo, chirimoyas cosechadas en noviembre presentaron niveles de actividad de PPO menores que en octubre. En general, la actividad de PPO y contenido total de fenoles de frutos tratados con L-cisteína no presentaron diferencias significativas con respecto a frutos no tratados después de 6 ó 12 días a $0{ }^{\circ} \mathrm{C}$. Los análisis de la actividad de PPO demostraron que ésta fue más alta en la parte externa de la pulpa que en el sector medio o interno. Estos resultados respaldarían la posibilidad de usar L-cisteína como un tratamiento de poscosecha para reducir el desarrollo de pardeamiento en chirimoya destinada a precortado.

Palabras clave: antioxidantes, Annona cherimola, polifenol oxidasa, fenólicos, evaluación sensorial.

\section{ACKNOWLEDGEMENTS}

This work was funded by project FONDECYT 1040011.

\section{LITERATURE CITED}

Alique, R. 1995. Residual effects of short-term treatments with high- $\mathrm{CO}_{2}$ on the ripening of cherimoya (Annona cherimola Mill.) fruit. J. Hortic. Sci. 70:609-615.

Alique, R., J.P. Zamorano, M.L. Calvo, C. Merodio, and J. De la Plaza. 1994. Tolerance of cherimoya (Annona cherimola Mill.) to cold storage. J. Amer. Soc. Hort. Sci. 119:524-528.

Amiot, M.J., A. Fleuriet, V. Cheynier, and J. Nicolas. 1997. Phenolic compounds and oxidative mechanism in fruit and vegetables. p. 51-85. In Tomas-Barberan, F.A., and R.J. Robins (eds.) Phytochemistry of fruit and vegetables. Oxford University Press, New York, USA.

Assis, J.S., R. Maldonado, T. Muñoz, M.I. Escribano, and C. Merodio. 2001. Effect of high carbon dioxide concentration on PAL activity and phenolic contents in ripening cherimoya fruit. Postharvest Biol. Technol. 23:33-39.

Biale, J.B., and D.E. Barcus. 1970. Respiration patterns in tropical fruits of the Amazon basin. Trop. Sci. 12:93-104.

Bradford, M.M. 1976. A rapid and sensitive method for the quantification of microgram quantities of protein utilizing the principle of protein-dye binding. Anal. Biochem. 72:248-254.
Buta, J.G., and J.A. Abbott. 2000. Browning inhibition of fresh-cut 'Anjou', 'Bartlett' and 'Bosc' pears. HortScience 35:1111-1113.

Campos-Vargas, R., O. Becerra, R. Baeza-Yates, V. Cambiazo, M. Gonzalez, A. Orellana et al. 2006. Seasonal variation in the development of chilling injury in O'Henry peaches. Sci. Hortic. 110:79-83.

Cantwell, M., and T. Suslow. 2002. Postharvest handling systems: Minimally processed fruits and vegetables. p. 445-463. In A.A. Kader (ed.) Postharvest technology of horticultural crops. University of California. Agriculture and Natural Resources. Publication 3311. University of California, Oakland, California, USA.

Cheng, W.C., and C.H. Crisosto. 1995. Browning potential, phenolic composition, and polyphenoloxidase activity of buffer extracts of peach and nectarine skin tissue. J. Amer. Soc. Hort. Sci. 120:835-838.

Couture, R., M.I. Cantwell, D. Ke, and M.E. Saltveit. 1993. Physiological attributes related to quality attributes and storage life of minimally processed lettuce. HortScience 28:723-725.

Gil, M.I., M.A. Conesa, and F. Artes. 2002. Quality changes in fresh cut tomato as affected by modified atmosphere packaging. Postharvest Biol. Technol. 25:199-207. 
de Castro, E., W.V. Biasi, and E.J. Mitcham. 2007. Quality of Pink Lady apples in relation to maturity at harvest, prestorage treatments, and controlled atmosphere during storage. HortScience 42:605-610.

Gonzalez-Aguilar, G.A., L. Zacarias, M.A. Perez-Amador, J. Carbonell, and M.T. Lafuente. 2000. Polyamine content and chilling susceptibility are affected by seasonal changes in temperature and by conditioning temperature in cold-stored 'Fortune' mandarin fruit. Physiol. Plant. 108:140-146.

Gooding, P.S., C. Bird, and S.P. Robinson. 2001. Molecular cloning and characterization of banana fruit polyphenol oxidase. Planta 213:748-757.

Gorny, J.R. 1997. A summary of CA and MA requirements and recommendations for fresh-cut (minimally processed) fruit and vegetables. p. 30-66. In J.R. Gorny (ed.) CA'97 Proceedings volume 5: Fresh-cut fruits and vegetable and MAP. International Controlled Atmosphere Research Conference, Davis. July 1318 1997. University of California, Department of Pomology, Davis, California, USA.

Gorny, J.R., B. Hess-Pierce, R.A. Cifuentes, and A.A. Kader. 2002. Quality changes in fresh-cut pear slices as affected by controlled atmospheres and chemical preservatives. Postharvest Biol.Technol.24:271-278.

Gutierrez, M., J.M. Lahoz, M.M. Sola, L. Pascual, and A.M. Vargas. 1994. Postharvest changes in total soluble solids and tissue $\mathrm{pH}$ of cherimoya fruit stored at chilling and non-chilling temperatures. J. Hortic. Sci. 69:459-463.

Kader, A.A. 2002a. Postharvest biology and technology: An overview. p. 39-47. In A.A. Kader (ed.) Postharvest technology of horticultural crops. University of California. Agriculture and Natural Resources. Publication 3311. University of California, Oakland, California, USA.

Kader, A.A. 2002b. Quality parameters of fresh-cut fruit and vegetable products. p. 11-20. In O. Lamikanra (ed.) Fresh-cut fruits and vegetables. Science, technology and market. CRC Press, Boca Raton, Florida, USA.

Ke, D., and M.E. Saltveit. 1989. Wound induced ethylene production, phenolic metabolism and susceptibility to russet spotting in iceberg lettuce. Physiol. Plant. 76:412-414.

Lahoz, J.M, M. Gutierrez, M.M. Sola, R. Salto, L. Pascual, M. Martinez-Cayuela, and A.M. Vargas. 1993. Ethylene in cherimoya fruit (Annona cherimola Mill.) under different storage conditions. J. Agric. Food Chem. 41:721-723.

Loaiza-Velarde, J.G., and M.E. Saltveit. 2001. Heat shocks applied either before or after wounding reduce browning of lettuce leaf tissue. J. Amer. Soc. Hort. Sci. 126:227-234.
Manugistics Inc. 2000. Statgraphics Plus 5. 543 p. Manugistic Product, Rockville, Maryland, USA.

Marrero, A., and A.A. Kader. 2006. Optimal temperature and modified atmosphere for keeping quality of fresh-cut pineapples. Postharvest Biol. Technol. 39:163-168.

Martinez, G., M. Serrano, M.T. Pretel, F. Riquelme, and F. Romojaro. 1993. Ethylene biosynthesis and physico-chemical changes during fruit ripening of cherimoya (Annona cherimola Mill.). J. Hortic. Sci. 68:477-483.

Martinez-Cayuela, M., L. Sanchez, M.J. Faus, and A. Gil. 1988. Cherimoya (Annona cherimola Mill.) polyphenoloxidase: monophenolase and dihydroxyphenolase activities. J. Food Sci. 53:11911194.

Melo, A.A.M., e E.V.D.B. Vilas-Boas. 2006. Inibição do escurecimento enzimático de banana maçã minimamente processada. Ciênc. Tecnol. Aliment., Campinas 26:110-115.

Muñoz, T., M.T. Sanchez-Ballesta, J. Ruiz-Cabello, M.I. Escribano, and C. Merodio. 2004. The acid metabolism of Annona fruit during ripening. J. Hortic. Sci. Biotech. 79:472-478.

Palma, T., J.M. Aguilera, and D.W. Stanley. 1993. A review of postharvest events in cherimoya. Postharvest Biol. Technol. 2:187-208.

Piagentini, A. M., J.C. Mendez, D.R. Guemes, and M.E. Pirovani. 2005. Modelling changes of sensory attributes for individual and mixed fresh-cut leafy vegetables. Postharvest Biol. Technol. 38:202-212.

Rathjen, A.H., and S.P. Robinson. 1992. Characterisation of a variegated grapevine mutant showing reduced polyphenol oxidase activity. Aust. J. Plant Physiol. 19:43-54.

Richard-Forget, F., P.M. Groupy, and J.J. Nicolas. 1992. L-cysteine as an inhibitor of enzymatic browning. 2. Kinetic studies. J. Agric. Food Chem. 40:21082113.

Rivas, N.D.J., and J.R. Whitaker. 1973. Purification and some properties of two polyphenol oxidases of Bartlett pears. Plant Physiol. 52:501-507.

Rocha, A.M.C.N., and A.M.M.B. Morais. 2001. Polyphenoloxidase activity and total phenolic content as related to browning of minimally processed 'Jonagored' apple. J. Sci. Food Agric. 82:120-126.

Sanchez, J.A., J.P. Zamorano, and R. Alique. 1998. Polygalacturonase, cellulase and invertase activities during cherimoya fruit ripening. J. Hort. Sci. Biotech. 73:87-92. 
Sanchez de Medina, L., M.C. Plata, M. Martinez-Cayuela, M.J. Faus, y A. Gil. 1986. Cambios en la actividad polifenoloxidasa, peroxidasa, catalasas y fosfatasa ácida de chirimoyo durante la maduración a temperatura y humedad controladas. Rev. Agroquim. Tecnol. Aliment. 26:529-538.

Singleton, V.L., and J.A. Rossi. 1965. Colorimetry of total phenolics with phosphomolybdic-phosphotungstic acid reagents. Am. J. Enol. Vitic. 16:144-157.

Siriphanich, J., and A.A. Kader. 1985. Effects of $\mathrm{CO}_{2}$ on total phenolics, phenylalanine ammonia lyase, and polyphenol oxidase in lettuce tissue. J. Amer. Soc. Hort. Sci. 110:249-253.

Valentines, M.C., R. Vilaplana, R. Torres, J. Usall, and C. Larrigaudiere. 2005. Specific roles of enzymatic browning and lignification in apple disease resistance. Postharvest Biol. Technol. 36:227-234.
Wakayama, T. 1995. Polyphenol oxidase activity in Japanese apples. Differences among cultivars and prevention by heat, ascorbic acid and reduced oxygen. p. 251-266. In Lee, C.Y., and J.R. Whitaker (eds.) Enzymatic browning and its prevention. American Chemical Society, Washington DC, USA.

Watada, A.E., P.N. Ko, and D.A. Minott. 1996. Factors affecting quality of fresh-cut horticultural products. Postharvest Biol. Technol. 9:115-125.

Wills, R., B. McGlasson, D. Graham, and D. Joyce. 1998. Postharvest and introduction to the physiology and handling of fruit, vegetables and ornamentals. $262 \mathrm{p}$. $4^{\text {th }}$ ed. CAB International, New York, USA. 